JE/EM-52

\title{
Sampling Approach for Characterization of the Scarboro Community, Oak Ridge, Tennessee
}

\author{
RECEIVED \\ FFR 171998 \\ 0.871
}

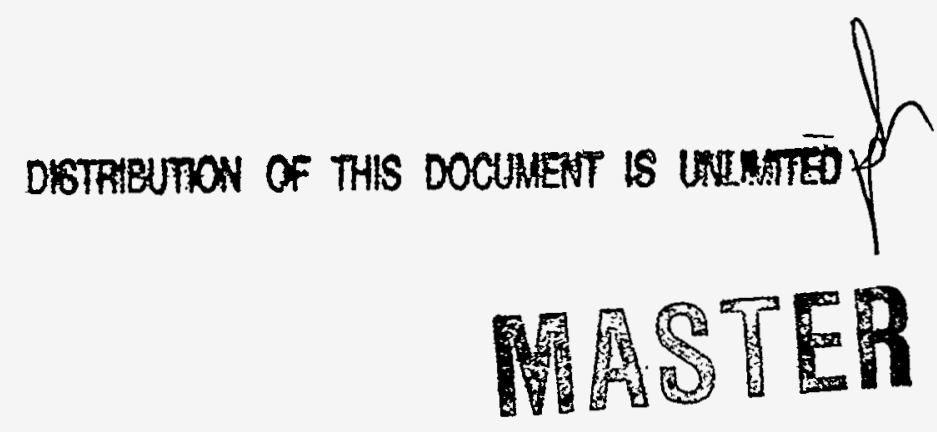




\section{DISCLAIMER}

This report was prepared as an account of work sponsored by an agency of the United States Government. Neither the United States Government nor any agency thereof, nor any of their employees, makes any warranty, express or implied, or assumes any legal liability or responsibility for the accuracy, completeness, or usefulness of any information, apparatus, product, or process disclosed, or represents that its use would not infringe privately owned rights. Reference herein to any specific commercial product, process, or service by trade name, trademark, manufacturer, or otherwise does not necessarily constitute or imply its endorsement, recommendation, or favoring by the United States Government or any agency thereof. The views and opinions of authors expressed herein do not necessarily state or reflect those of the United States Government or any agency thereof. 


\section{DISCLAIMER}

Portions of this document may be illegible electronic image products. Images are produced from the best available original document. 
JE/EM-52

\title{
Sampling Approach for Characterization of the Scarboro Community, Oak Ridge, Tennessee
}

Date Issued-January 1998

\author{
Prepared by \\ Jacobs EM Team \\ 125 Broadway Avenue \\ Oak Ridge, Tennessee \\ under contract DE-AC05-93OR22028 \\ Prepared for \\ U.S. Department of Energy \\ Office of Environmental Management
}




\section{CONTENTS}

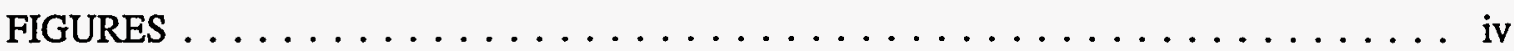

TABLES $\ldots \ldots \ldots \ldots \ldots \ldots \ldots \ldots \ldots \ldots \ldots \ldots \ldots \ldots \ldots \ldots$ iv

ACRONYMS AND ABBREVIATIONS $\ldots \ldots \ldots \ldots \ldots \ldots \ldots \ldots \ldots \ldots$ v

1. SITE LOCATION $\ldots \ldots \ldots \ldots \ldots \ldots \ldots \ldots \ldots \ldots \ldots \ldots$

2. SITE DESCRIPTION $\ldots \ldots \ldots \ldots \ldots \ldots \ldots \ldots \ldots \ldots$

3. PHYSICAL SETTING $\ldots \ldots \ldots \ldots \ldots \ldots \ldots \ldots \ldots \ldots \ldots \ldots$

3.1 DEMOGRAPHY AND LAND USE $\ldots \ldots \ldots \ldots \ldots \ldots \ldots \ldots \ldots 1$

3.2 GEOLOGY $\ldots \ldots \ldots \ldots \ldots \ldots \ldots \ldots \ldots \ldots \ldots \ldots \ldots \ldots \ldots \ldots$

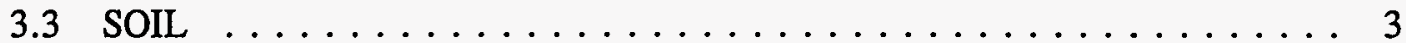

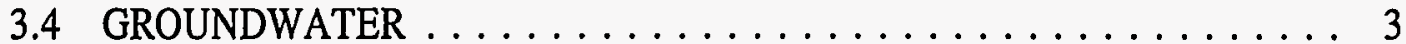

3.5 SURFACE WATER $\ldots \ldots \ldots \ldots \ldots \ldots \ldots \ldots \ldots \ldots \ldots \ldots$

3.6 DRAINAGE PATTERNS $\ldots \ldots \ldots \ldots \ldots \ldots \ldots \ldots \ldots \ldots$

3.7 CONTAMINANTS OF CONCERN $\ldots \ldots \ldots \ldots \ldots \ldots \ldots \ldots$

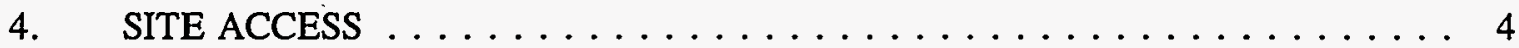

5. SAMPLING AND ANALYSIS $\ldots \ldots \ldots \ldots \ldots \ldots \ldots \ldots \ldots$

5.1 RATIONALE FOR SAMPLING $\ldots \ldots \ldots \ldots \ldots \ldots \ldots \ldots \ldots$

6. LABORATORY DELIVERABLES/DATA VALIDATION $\ldots \ldots \ldots \ldots .8$

6.1 EVALUATION LEVEL $\ldots \ldots \ldots \ldots \ldots \ldots \ldots \ldots \ldots$

7. QC SAMPLE FREQUENCY $\ldots \ldots \ldots \ldots \ldots \ldots \ldots \ldots$ 


\section{FIGURES}

Figure No.

Page

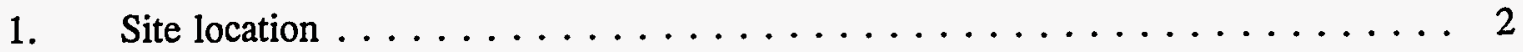

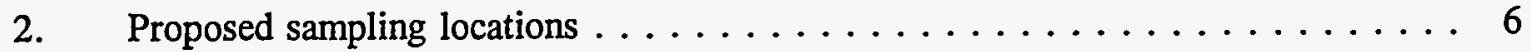

\section{TABLES}

Table No.

Page

1. Samples, analytes, and target constituents, Scarboro Community . . . . . . . 5 


\section{ACRONYMS AND ABBREVIATIONS}

$\begin{array}{ll}\text { DOE } & \text { U.S. Department of Energy } \\ \mathrm{ft} & \text { foot } \\ \mathrm{GM} & \text { Geiger-Müller } \\ \mathrm{ha} & \text { hectare } \\ \mathrm{m} & \text { meter } \\ \mathrm{ORR} & \text { Oak Ridge Reservation } \\ \mathrm{QC} & \text { quality control } \\ \mathrm{Tc} & \text { technetium }\end{array}$




\section{SITE LOCATION}

The Scarboro Community, Oak Ridge, Tennessee, is located northwest of the Oak Ridge Y-12 Plant along the U.S. Department of Energy (DOE) Oak Ridge Reservation (ORR) boundary. The community is located in east Oak Ridge and is bounded to the west by East Fork Ridge and to the east by Pine Ridge (Fig. 1).

\section{SITE DESCRIPTION}

The Scarboro Community is a small urban community in the city of Oak Ridge, Tennessee. It is located approximately $457 \mathrm{~m}(1,500 \mathrm{ft})$ northwest of the Oak Ridge Y-12 Plant along the DOE ORR boundary. Pine Ridge separates the Scarboro Community from the Y-12 Plant area. The community occupies an area of approximately 101 ha (250 acres).

Note: This community is not on DOE-owned property.

\section{PHYSICAL SETTING}

Topography of the Scarboro Community consists of gently rolling hills that have been cleared for residential use. The Scarboro saddle consists of a number of depressions in the ridge that may act as a conduit for air movement within the community. Pine Ridge rises sharply to the south. It is unknown whether the sampling area is in a floodplain and whether wetlands are present.

\subsection{DEMOGRAPHY AND LAND USE}

Land in the Scarboro Community was cleared and divided into lots ranging in size from approximately 0.1 to 0.2 ha ( 0.25 to 0.5 acre). The Scarboro Community Center Park, and various churches and small businesses are located in this area.

\subsection{GEOLOGY}

The Scarboro Community is underlain by the upper Rome Formation and the Chickamauga Group. According to P. J. Leminski (Geologic Mapping of the Oak Ridge K-25 Site, Oak Ridge, Tennessee, 1994), the Rome Formation is the oldest rock unit exposed in the Oak Ridge area. The upper Rome Formation is composed primarily of sandstone, siltstone, and 


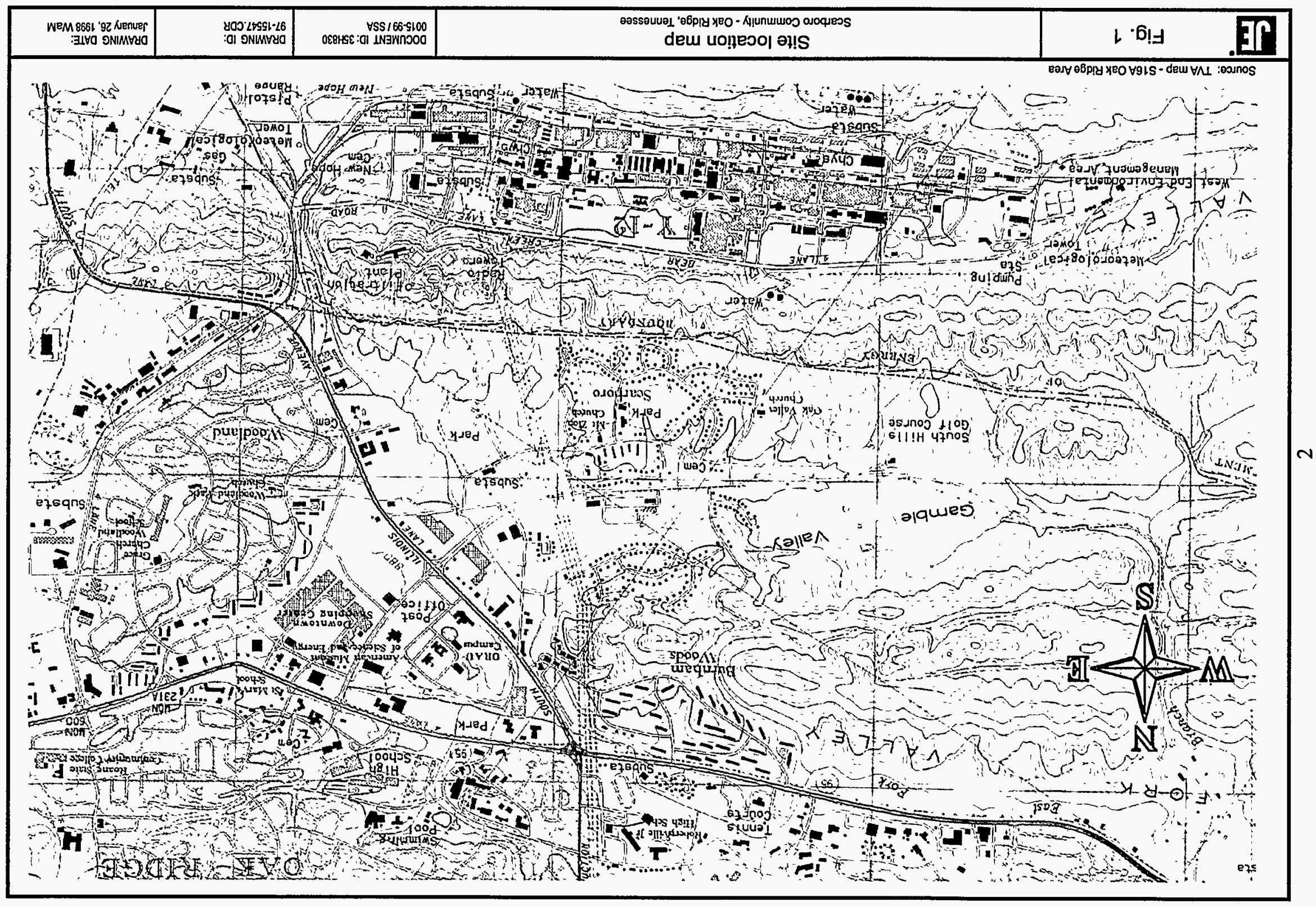


shale. The sandstone is silica and hematite cemented and mostly fine- to medium-grained. The erosional resistance of the sandstone is responsible for the development of Pine Ridge which forms the southern boundary of the Scarboro Community. The northern part of the Scarboro Community is underlain by the Chickamauga Group of East Fork Valley (Oak Ridge Valley). According to R. D. Hatcher, Leminski, et al. (Report on the Geology of the Oak Ridge Reservation, ESD Pub. No. 3860, 1992), this younger geologic unit was placed adjacent to the older Rome Formation by a thrust fault. The Chickamauga Group consists almost entirely of limestone-dominated lithologies. This section of the Chickamauga Group consists predominantly of fossiliferous, thin to thick-bedded, fine-grained limestone interbedded with thin-to-massive beds of micrite and shale. In the lower and upper portions of the section, the limestone is predominantly argillaceous (high clay content). Near the upper part of the section a predominantly dark-gray to black chert bed underlies a metabentonite.

\subsection{SOIL}

The Scarboro Community is underlain by a silty loam commonly found on foot slopes

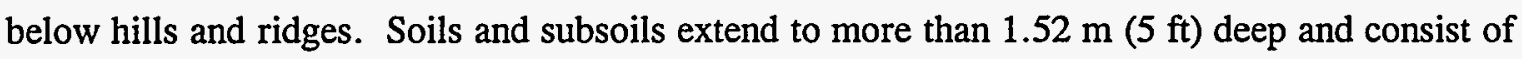
three distinct regions. The upper region is strong brown silt loam; the middle region is red, silty clay with mottled shades of brown; the lower region is red, shaly, silty clay loam. Soils are strong-to-medium in acidity except in some areas where surface soils have been limed. Soils of this type are typically low in fertility but high in water capacity. Overall, soil has a fair-to-good potential for urban use.

\subsection{GROUNDWATER}

No groundwater monitoring wells have been installed by DOE in the Scarboro Community; however, city water is available as drinking water to the community. Shallow groundwater is expected to follow the topography which runs north toward East Fork Poplar Creek.

\subsection{SURFACE WATER}

Three small intermittent drainage areas intersect the Scarboro Community. These small drains flow north, converge, and ultimately join East Fork Poplar Creek approximately $609 \mathrm{~m}$ $(2,000 \mathrm{ft})$ north of the community. 


\subsection{DRAINAGE PATTERNS}

Drainage patterns generally follow the topography which run predominantly north toward East Fork Poplar Creek.

\subsection{CONTAMINANTS OF CONCERN}

Based on the ongoing remedial investigation for the $Y-12$ Plant, mercury and radionuclides are two primary contaminants of concern, and therefore, are the target contaminants of concern for this investigation. Table 1 of this sampling approach presents the samples, analytes, and target constituents used in this investigation.

\section{SITE ACCESS}

The city of Oak Ridge will be contacted before initiation of any sampling activities at this site. All underground utilities located near the proposed sampling locations will be clearly marked and identified. In cases where proposed sampling locations fall on private property, consent of the property owner will be obtained before sampling activities begin. Utility maps are available, but are not included in this document. A. B. Perkins, DOE, is the Jacobs Environmental Management Team point-of-contact.

\section{SAMPLING AND ANALYSIS}

\subsection{RATIONALE FOR SAMPLING}

The purpose of this investigation is to validate measurements taken at the perimeter air monitor 46 (located in the Scarboro Community) and external gamma data collected during past flyover surveys. Five sampling tasks will be performed to validate these measurements. These tasks include biased sampling of residential properties, random sampling of residential properties, ORR boundary sampling, focused soil sampling in the Scarboro saddle, and surface water and sediment sampling in the Scarboro tributaries (Fig. 2). Additionally, a radiological walkover of representative areas of the Scarboro Community will be performed.

Biased soil sampling from residential properties will be performed and will include resident input. One soil sample will be collected from each selected property using a hand auger. 
Table 1. Samples, analytes, and target constituents, Scarboro Community, Oak Ridge, Tennessee

\begin{tabular}{|c|c|c|c|c|c|c|c|}
\hline $\begin{array}{l}\text { Pratyfy } \\
\% \text { watiny }\end{array}$ & 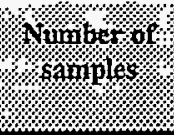 & \%ypolicabor & $\begin{array}{l}\text { Annlytan } \\
\% \text { method } \\
\%\end{array}$ & 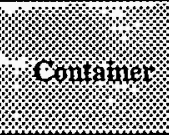 & 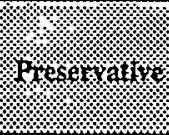 & 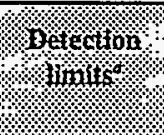 & 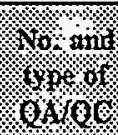 \\
\hline $\begin{array}{l}\text { Total } \mathrm{Hg} \\
\text { in soil/ } \\
\text { sediment }\end{array}$ & $\begin{array}{l}\text { Sediment: } 3 \\
\text { Soil: } 46\end{array}$ & $\begin{array}{l}\text { FS-8.1.1, } \\
\text { FS-8.1.2, } \\
\text { or FS-8.1.4 }\end{array}$ & 7471 & $\begin{array}{l}\text { 4-oz amber } \\
\text { glass }\end{array}$ & $\begin{array}{l}\text { Cool to } 4^{\circ} \mathrm{C} \\
\pm 2^{\circ} \mathrm{C}\end{array}$ & $23 \mathrm{mg} / \mathrm{kg}$ & $\begin{array}{l}1 / 20 \\
\text { samples }\end{array}$ \\
\hline $\begin{array}{l}\text { Gross } \\
\text { alpha/ } \\
\text { beta in } \\
\text { surface } \\
\text { water }\end{array}$ & 3 & FS-6.1.1 & 900 & $1-\mathrm{gal}^{3}$ & $\begin{array}{l}\mathrm{HNO}_{3} \text { to } \mathrm{pH} \\
<2.0\end{array}$ & $\begin{array}{l}\text { Based on } \\
\text { laboratory } \\
\text { selected }\end{array}$ & $\begin{array}{l}1 / 20 \\
\text { samples }\end{array}$ \\
\hline $\begin{array}{l}\text { Gross } \\
\text { alpha/ } \\
\text { beta in } \\
\text { soil/ } \\
\text { sediment }\end{array}$ & $\begin{array}{l}\text { Sediment: } 3 \\
\text { Soil: } 46\end{array}$ & $\begin{array}{l}\text { FS-8.1.1, } \\
\text { FS-8.1.2, } \\
\text { or FS-8.1.4 }\end{array}$ & 9310 & $\begin{array}{l}500-\mathrm{g} \\
\text { polyethylene }\end{array}$ & $\begin{array}{l}\text { Cool to } 4^{\circ} \mathrm{C} \\
\pm 2^{\circ} \mathrm{C}\end{array}$ & $\begin{array}{l}\text { Based on } \\
\text { laboratory } \\
\text { selected }\end{array}$ & $\begin{array}{l}1 / 20 \\
\text { samples }\end{array}$ \\
\hline $\begin{array}{l}\text { Isotopic } \\
\text { uranium } \\
\text { in water }\end{array}$ & 3 & FS-6.1.1 & $\begin{array}{l}901.1 \\
908^{b}\end{array}$ & $1-\mathrm{gal}^{3}$ & $\begin{array}{l}\mathrm{HNO}_{3} \text { to } \mathrm{pH} \\
<2.0\end{array}$ & $0.59 \mathrm{pCi} / \mathrm{L}$ & $\begin{array}{l}1 / 20 \\
\text { samples }\end{array}$ \\
\hline $\begin{array}{l}\text { Isotopic } \\
\text { uranium } \\
\text { in soil/ } \\
\text { sediment }^{b}\end{array}$ & $\begin{array}{l}\text { Sediment: } 3 \\
\text { Soil: } 46\end{array}$ & $\begin{array}{l}\text { FS-8.1.1, } \\
\text { FS-8.1.2, } \\
\text { or FS-8.1.4 }\end{array}$ & $\begin{array}{l}\text { Gama spec } \\
908^{b}\end{array}$ & $\begin{array}{l}500-\mathrm{g} \\
\text { polyethylene }\end{array}$ & $\begin{array}{l}\text { Cool to } 4^{\circ} \mathrm{C} \\
\pm 2^{\circ} \mathrm{C}\end{array}$ & $0.16 \mathrm{pCi} / \mathrm{g}$ & $\begin{array}{l}1 / 20 \\
\text { samples }\end{array}$ \\
\hline
\end{tabular}

aNote: Detection limits listed are based on the preliminary remediation goals for the listed analytes.

Isotopic analysis will be run only if the gama spec indicates the presence of uranium above background.

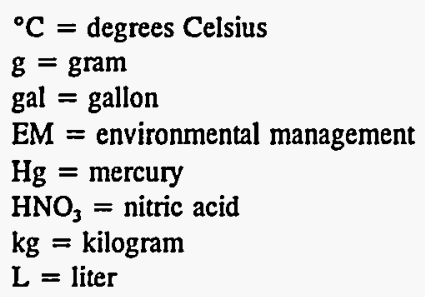

$$
\begin{aligned}
& \mathrm{mg}=\text { milligram } \\
& \mathrm{No} .=\text { number } \\
& \mathrm{oz}=\text { ounce } \\
& \mathrm{pCi}=\text { picocurie } \\
& \mathrm{QA}=\text { quality assurance } \\
& \mathrm{QC}=\text { quality control } \\
& \mathrm{SOP}=\text { standard operating procedure }
\end{aligned}
$$




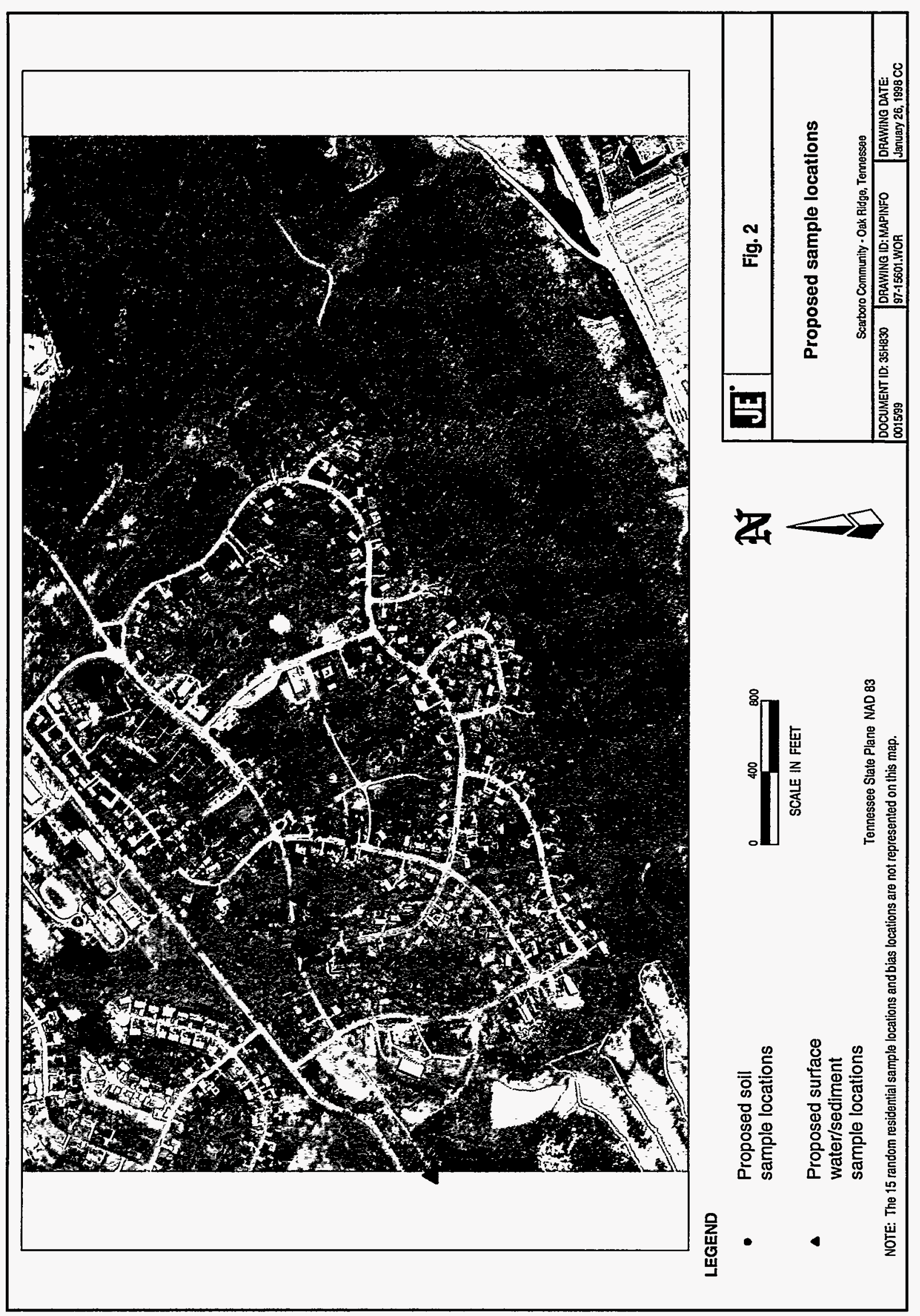


Random soil sampling will be performed at 15 residential properties (roughly 10 percent of the residential properties in the community). One soil sample will be collected from each of these properties using a hand auger.

Soil samples will be collected in the Scarboro Community near the ORR property boundary along a transect parallel to the boundary line. The transect will connect the southwestern corner and the southeastern corner of the community. Soil samples will be collected at $50 \mathrm{~m}$ (164 ft) intervals for approximately $1,000 \mathrm{~m}(3,281 \mathrm{ft}$ ) (approximately 20 samples) using a hand auger.

Focused soil sampling will be conducted in a saddle which is located in the western part of the Scarboro Community. Three transects will divide the saddle. Two soil samples will be collected from each transect. The samples will be collected on either side of the creek that flows through the low point in the saddle. Transects will be located south of Spellman Avenue, south of the intersection of South Dillard Avenue and South Fisk Avenue, and south of Wilberforce Avenue. Soil samples will be collected using a hand auger.

Surface water and sediment samples will be collected from three tributaries flowing through the community. One surface water and sediment sample set will be collected downstream of a spring located east of South Hills Golf Club. A second set of samples will be collected at the confluence of two streams located west of Hampton Lane in the northern part of the community. A third set of samples will be collected in a stream south of Wilberforce Avenue and east of the community cemetery. Surface water samples will be collected using direct-fill methods to the extent practical and may be collected using a stainless steel dipper, if conditions warrant. Sediment samples may be collected using a stainless steel spade or scoop, to the extent practical, or the hand auger method may be used.

All samples collected will be analyzed for the target constituents (see Table 1). Sample results will be evaluated against the Final Report on the Background Soil Characterization Project at the Oak Ridge Reservation, Oak Ridge, Tennessee, DOE/OR/01-1175-V1, issued October 1993, to determine if elevated concentrations of target constituents are present in the Scarboro Community. All sampling activities, decontamination of sampling equipment, and quality control will be conducted in accordance with standard operating procedures written in accordance with the U.S. Environmental Protection Agency, Region 4 Quality Assurance Manual. If soil samples are collected in vegetated areas, the vegetation will be removed before augering. On completion of sampling activities at each sample location, the borehole will be backfilled with soil and seeded, if necessary. 
A radiological walkover survey will be performed at the Scarboro Community Center Park and selected residences. The lack of buildings, trees and large vegetation in this area provides a higher probability of potential airborne deposition. This survey will be performed using a sodium iodide gamma scintillation detector and a Geiger-Müller (GM) detector. A data collection system will be used, such that radiological readings correspond to known geographical data points (e.g., Global Positioning System or equivalent).

The sodium iodide detector will be used qualitatively to note any increases in background activity and to help determine radiological isopleths that may exist as a result of the community's geography. The target constituent is uranium and its associated decay products. The uranium decay products emit one or more beta particles or gamma rays per decay. These daughter products are always present with the uranium parent. GM detectors respond to the more penetrating beta and gamma radiation as well as alpha radiation, thus reliably detecting uranium and providing a conservative upper estimate of any uranium present. Additionally, efficiencies for the GM detectors will be determined using a ${ }^{99} \mathrm{Tc}$ source that gives off a beta particle consistent in energy levels with the uranium daughters.

\section{LABORATORY DELIVERABLES/DATA VALIDATION}

\subsection{EVALUATION LEVEL}

Screening: Yes

(Analytical samples will be screened for radionuclides before shipment to laboratory.)

Definitive: Yes

(Laboratory analytical results and radiological walkover data from the Scarboro Community Center park.)

Percent validation:

100 percent for definitive data.

\section{Electronic data deliverable: Yes}

For definitive data. 
Estimated number of samples:

3 (soil and sediment).

Sample delivery groups:

1 [water and quality control (QC)].

\section{QC SAMPLE FREQUENCY}

A QC sample will be taken for field duplicates, field rinsates, matrix spikes, and laboratory duplicates at a frequency of 1 per 20 samples. 